\title{
Calcitization of aragonitic bryozoans in Cenozoic tropical carbonates from East Kalimantan, Indonesia
}

\author{
Emanuela Di Martino $^{1} \cdot$ Paul D. Taylor ${ }^{1} \cdot$ Anatoliy B. Kudryavtsev $^{2} \cdot$ \\ J. William Schopf ${ }^{2,3}$
}

Received: 9 November 2015 / Accepted: 15 January 2016 / Published online: 8 February 2016

(C) The Author(s) 2016. This article is published with open access at Springerlink.com

\begin{abstract}
Aragonite is commonly lost during the diagenesis of carbonate rocks, producing a significant bias in the fossil record. However, taphonomic loss of aragonitic biota can be nullified when skeletal aragonite is replaced by calcite. Here we report calcification of the originally aragonitic skeletons of two cheilostome bryozoan taxaReussirella sp. and Reptadeonella toddi-in muddy reefs from the Miocene of East Kalimantan. The calcitic composition of these Miocene fossils is shown using Raman spectroscopy, which enabled precise in situ analysis of skeletal walls without contamination from sediment or chamber-filling cement. Compared with Recent and fossil relatives preserved in original acicular aragonite, the calcitized bryozoans have skeletons with blocky microstructures, undulose extinction patterns, and small patches of highly birefringent acicular crystals that may be aragonite relics. Calcitization of the bryozoans as well as scleractinian corals in the East Kalimantan Miocene reefs was probably made possible because of the high input of fine-grained clastic sediments that partially sealed the buried skeletons, although other factors must be invoked to explain the lack of calcitized molluscs in the same reefs. A general conclusion from this study is that not all bryozoans preserved in
\end{abstract}

Emanuela Di Martino

e.di-martino@nhm.ac.uk

1 Department of Earth Sciences, Natural History Museum, Cromwell Road, London SW7 5BD, UK

2 Center for the Study of Evolution and the Origin of Life (Institute of Geophysics and Planetary Physics) and NASA Astrobiology Institute, University of California, Los Angeles, CA 90095-1567, USA

3 Department of Earth and Space Sciences, Molecular Biology Institute, University of California, Los Angeles, CA 90095-1567, USA deposits from which aragonitic molluscs have been lost through diagenetic dissolution possessed original skeletons of calcite. The potential for selective loss of molluscs but not bryozoans and corals must be taken into account during biofacies analysis.

Keywords Biomineralogy $\cdot$ Calcitization $\cdot$ Diagenesis . Cheilostomata $\cdot$ Miocene

\section{Introduction}

Mineralogy has a major influence on fossilization potential. In carbonate settings, it is commonplace for aragonitic skeletons to be lost by dissolution during diagenesis. Aragonite, as a metastable form of $\mathrm{CaCO}_{3}$, is appreciably more soluble than calcite under normal circumstances, leading to a strong taphonomic bias on the composition of fossil biotas (e.g., Brachert and Dullo 2000; Cherns and Wright 2000; Wright et al. 2003). Importantly, however, aragonite loss does not always result in complete destruction of fossils as various processes may permit the preservation of originally aragonitic fossils in altered forms (McAlester 1962; Bush and Bambach 2004; Kidwell 2005; Kidwell et al. 2005; Kowalewski et al. 2002; Cherns et al. 2008; Tomašových and Schlögl 2008; Caron and Nelson 2009; Foote et al. 2015).

Sorby (1879) was the first to mention the process of calcitization, describing it as 'molecular change'. The term 'neomorphism' was coined by Folk (1965) and introduced as an 'inclusive term of ignorance' to embrace those mineralogical processes in which gross composition remains constant. Subsequent authors used the term neomorphism to refer both to the inversion of aragonite to calcite, and also the recrystallization of high-magnesium calcite to 
low-magnesium calcite during diagenetic stabilization (e.g., Hendry et al. 1995; Maliva 1995, 1998; Maliva et al. 2000).

Depending on the species concerned, cheilostome bryozoans are capable of constructing their skeletons using calcite, aragonite or a combination of these minerals (Smith et al. 2006; Taylor et al. 2009). Available taphonomic evidence suggests that aragonite first appeared in cheilostome during the latest Cretaceous, while mineralogical data show that at least four clades had independently acquired aragonitic or bimineralic skeletons by the middle Eocene (Smith et al. 2006; Taylor et al. 2009). Aragonite is widely distributed among modern cheilostome genera and families, with a higher proportion of aragonitic and bimineralic species in tropical faunas (Taylor et al. 2009). Unfortunately, the Cretaceous-Cenozoic fossil record of tropical bryozoans, which are most likely to contain aragonite, is poor compared to higher latitudes (Taylor and Di Martino 2014), preventing the creation of a more complete picture of the distribution of aragonite in bryozoans through geological time. The current study was prompted by the unexpected discovery of skeletally preserved specimens of two bryozoan genera-Reussirella and Reptadeonella-which today have aragonite skeletons, in Miocene sediments of East Kalimantan where skeletal aragonite was believed to have been lost by diagenetic dissolution.

Our first aim was to ascertain, using Raman spectroscopy, whether the preserved skeletons of these bryozoans were still composed of aragonite, or if the aragonite had been replaced by calcite. Neomorphic replacement of aragonite by calcite was found to have occurred, with concomitant textural changes in the structure of the skeleton, which we describe using thin-sections and scanning electron microscopy (SEM). Our study provides an example of how high levels of fine-grained clastic sediment input in the muddy Miocene reefs of East Kalimantan has allowed preservation of some taxa (bryozoans and corals) with metastable aragonitic skeletons in a setting where aragonite has been lost in others (molluscs). Selective preservation of originally aragonitic biota by calcitization has implications for biofacies analysis.

\section{Geological setting}

The research area is located in the eastern part of the Kutai Basin, one of the largest sedimentary basins in Borneo, which was formed during a period of widespread Paleogene extension and subsidence initiated in the middle Eocene (Moss and Wilson 1998). High rates of Neogene uplift and associated erosion of the central ranges of the Borneo landmass resulted in the progradation of large deltas and substantial siliciclastic input into basinal areas to the north and east (Wilson and Moss 1999). Early to middle Miocene deltas prograded rapidly eastwards, contributing to the infilling of the Kutai Basin (Moss and Chambers 1999; Hall and Nichols 2002). Within this depositional regime, Miocene carbonates formed as delta-front reefs (Wilson 2005; Santodomingo et al. 2015), shelf-edge reefs (Marshall et al. 2015; Novak et al. 2013; Novak and Renema 2015), and small carbonate platforms (Wilson et al. 2012), along the seaward margin of the Mahakam Delta where they were strongly influenced by siliciclastic input throughout their evolution (Wilson 2005; Lokier et al. 2009; Marshall et al. 2015). These carbonates have been interpreted as transitional shelf sediments deposited between deltaic and deepmarine facies (Allen and Chambers 1998).

The study sites are two reef complexes in the Samarinda area in East Kalimantan (Fig. 1), the Batuh Putih $\left(0.466260^{\circ} \mathrm{S}\right.$; $117.297500^{\circ} \mathrm{E} ; \quad$ Fig. 1c) and Stadion $\left(0.584670^{\circ} \mathrm{S}\right.$; $117.119830^{\circ} \mathrm{E}$; Fig. 1d) sections, magnetostratigraphically dated at $\sim 15$ and 11.6 Ma, respectively (Marshall et al. 2015).

The Batu Putih section has been interpreted as a patch reef that formed on the shelf edge in front of the rapidly prograding paleo-Mahakam Delta. The weakly lithified limestone beds are interbedded with fossiliferous shale and marl (Marshall et al. 2015). The reef was initiated by the buildup of larger benthic foraminifera banks with platy corals forming a substrate for a diverse reef of corals, algae, bryozoans, molluscs, and echinoids. The reef-forming organisms are still in life position, probably because they were rapidly buried (Wilson 2005).

The Stadion section shows a progression from platy corals in the lower part to larger head corals above, with associated larger benthic foraminifera, bryozoans, and coralline algae (Marshall et al. 2015).

Bryozoans are restricted, in both sections, to the coral sheetstone facies characterized by dominant thin-platy corals and occasional branching coral fragments, forming a sheetstone fabric in a muddy matrix, with subordinate larger benthic foraminifera, calcareous algae in low proportion, sparse cidaroid echinoid spines and fragments of calcitic gastropods and bivalves (Novak and Renema 2015; Santodomingo et al. 2015).

\section{Materials and methods}

This study utilizes modern and fossil specimens of two cheilostome bryozoan taxa known at the present-day to biomineralize skeletons composed of aragonite: (1) Reussirella ('Anasca': Cupuladriidae; Fig. 2a), and (2) Reptadeonella ('Ascophora': Adeonellidae; Fig. 2b). Whereas Reussirella is a free-living bryozoan with small discoidal colonies, Reptadeonella is an encruster growing as sheets on hard substrates. For each taxon, three specimens were selected: a modern representative with a pristine aragonite skeleton; a fossil from a deposit containing molluscs with preserved 

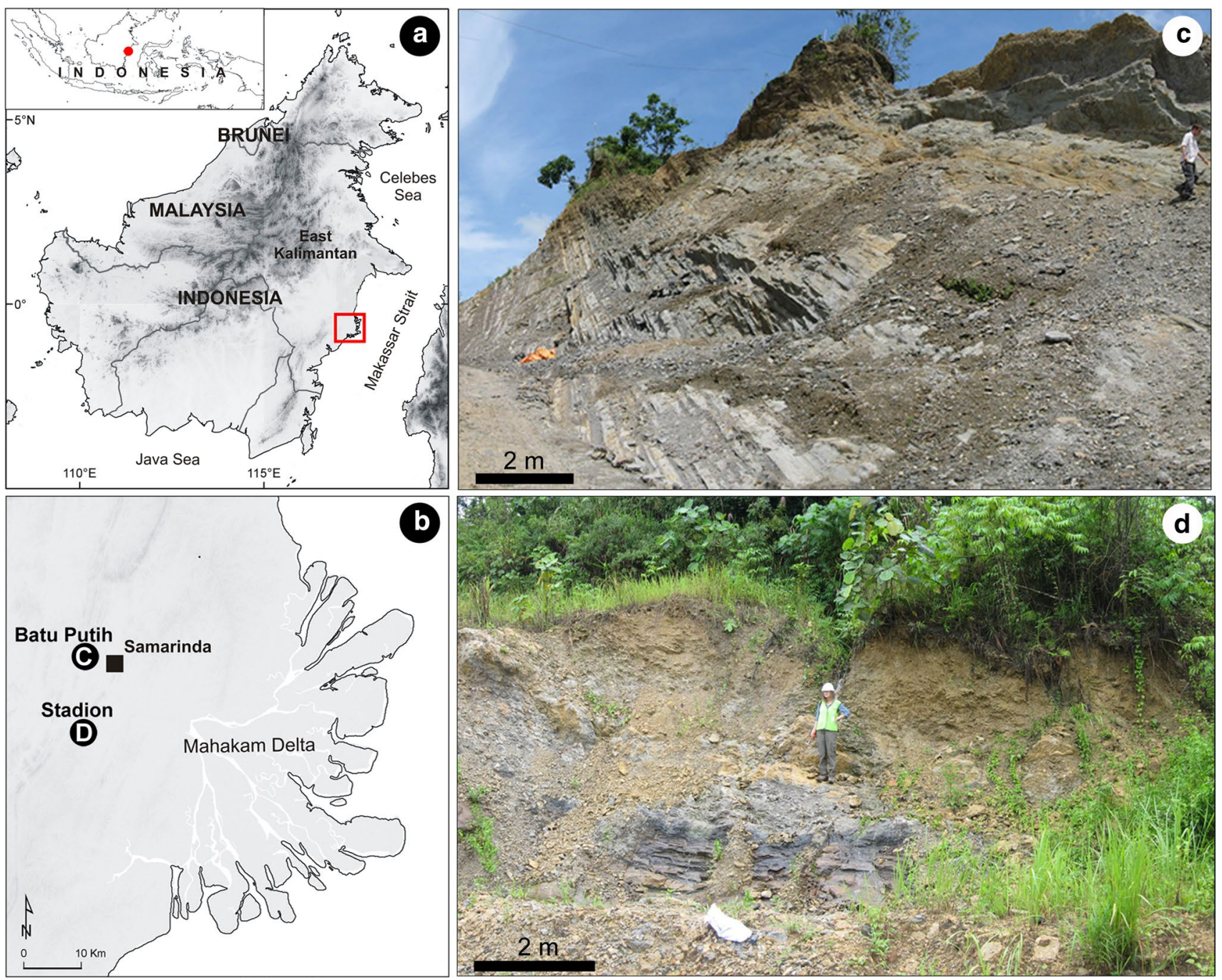

Fig. 1 Location of the research area. a Location of East Kalimantan on Borneo in Indonesia. The red square indicates the research area. b Location of Samarinda city and the Batu Putih and Stadion sections, east of the present-day Mahakam Delta. c Outcrop photograph of the Batu Butih section. d Outcrop photograph of the Stadion section skeletal aragonite; and a fossil from the study sites in East Kalimantan where the expected aragonitic molluscs are lacking (presumably as a result of dissolution during diagenesis). All of these samples are conserved in the collections of the Natural History Museum, London (NHMUK).

Raman spectroscopy provides an excellent tool for determining the biomineral/s present in bryozoan skeletons, both living and fossil. It has several advantages over other methods of mineralogical analysis; in particular, it is non-destructive, non-invasive, confocal, and permits point analyses that enable the distributions of calcite and aragonite to be determined at submicron $(\sim 0.8 \mu \mathrm{m})$ lateral spatial resolution (Taylor et al. 2008). The Raman spectra for calcite and aragonite are sufficiently distinct to allow unequivocal determination of these two polymorphs in both Recent and fossil bryozoan skeletons. For the present study, point mineralogical analyses were obtained initially from the frontal walls of the bryozoan zooids; if these walls proved to be aragonitic, additional analyses were made of orificial rims, basal walls, and/or avicularian crossbars to test for a possible bimineralic composition on the basis that in bimineralic species one or more of these structures will be calcitic (Taylor et al. 2008). A T64000 triple-stage laserRaman system with a Coherent Innova 90 argon ion laser projected through an Olympus BX41 microscope located in the Schopf lab at UCLA was employed. Prior to analysis, the fossil bryozoans from East Kalimantan were first soaked in a dilute solution of the detergent Quaternary-O to remove clay particles and then cleaned ultrasonically.

Following laser Raman spectroscopy, the same samples were embedded in resin, polished, and thin-sectioned. To study skeletal ultrastructure, polished sections were lightly 
a Reussirella sp.

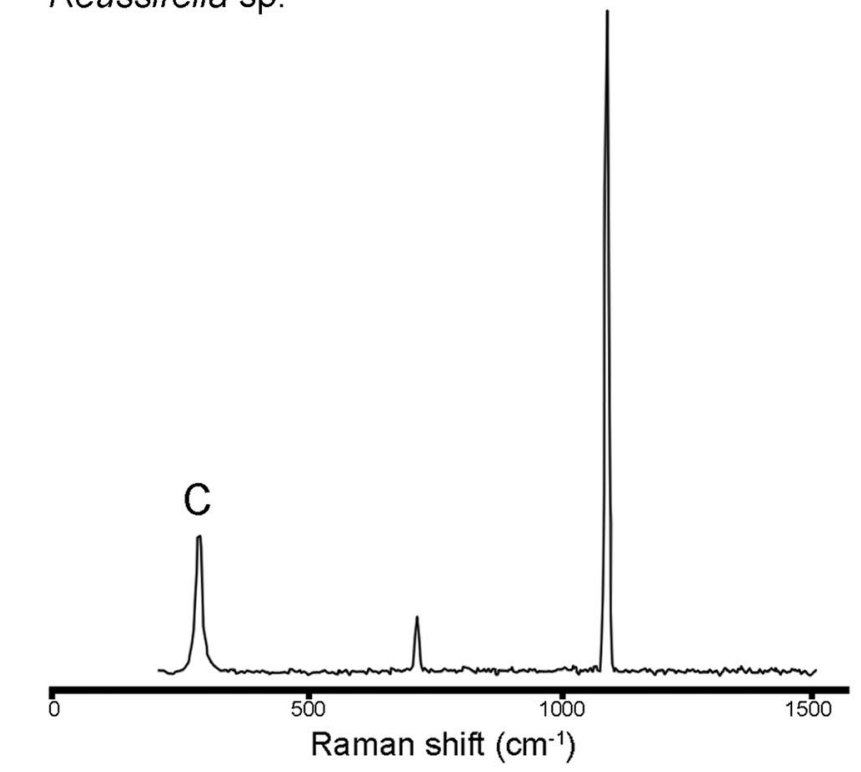

(b)
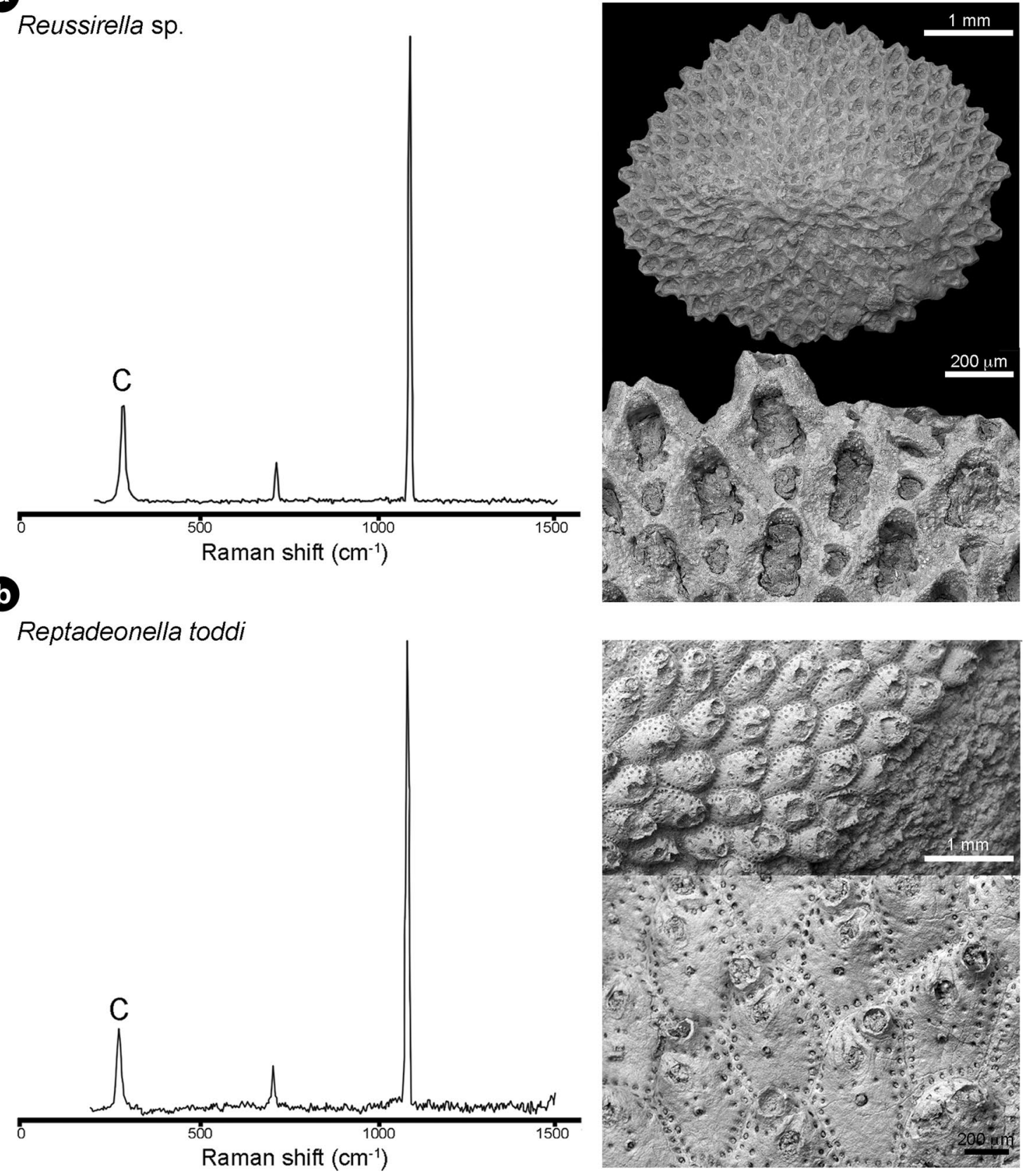

Fig. 2 Representative Raman spectra and SEM images of a Reussirella sp. and b Reptadeonella toddi from the Miocene of East Kalimantan. Raman bands diagnostic of calcite are indicated on the spectra with the letter C. SEM images show a discoidal, free-living colony-

etched using commercial acetic acid and then studied without coating using a FEI Quanta 650 FEG SEM at the NHMUK. This instrument was operated at low vacuum and images were obtained with a backscattered-electron detector. Thin-sections were cut in planes perpendicular to the colony frontal surface, and studied and photographed using a petrographic microscope. form of Reussirella sp. (NHMUK PI BZ 6875), and an encrusting colony of Reptadeonella toddi (NHMUK PI BZ 6915), with closeups of the zooids; note the well-preserved appearance of the skeletons

\section{Results}

\section{Mineralogy}

Figure 2 shows averaged laser Raman spectra obtained from one colony of the cupuladriid Reussirella sp. (Fig. 2a) and three of Reptadeonella toddi (Fig. 2b) from the 

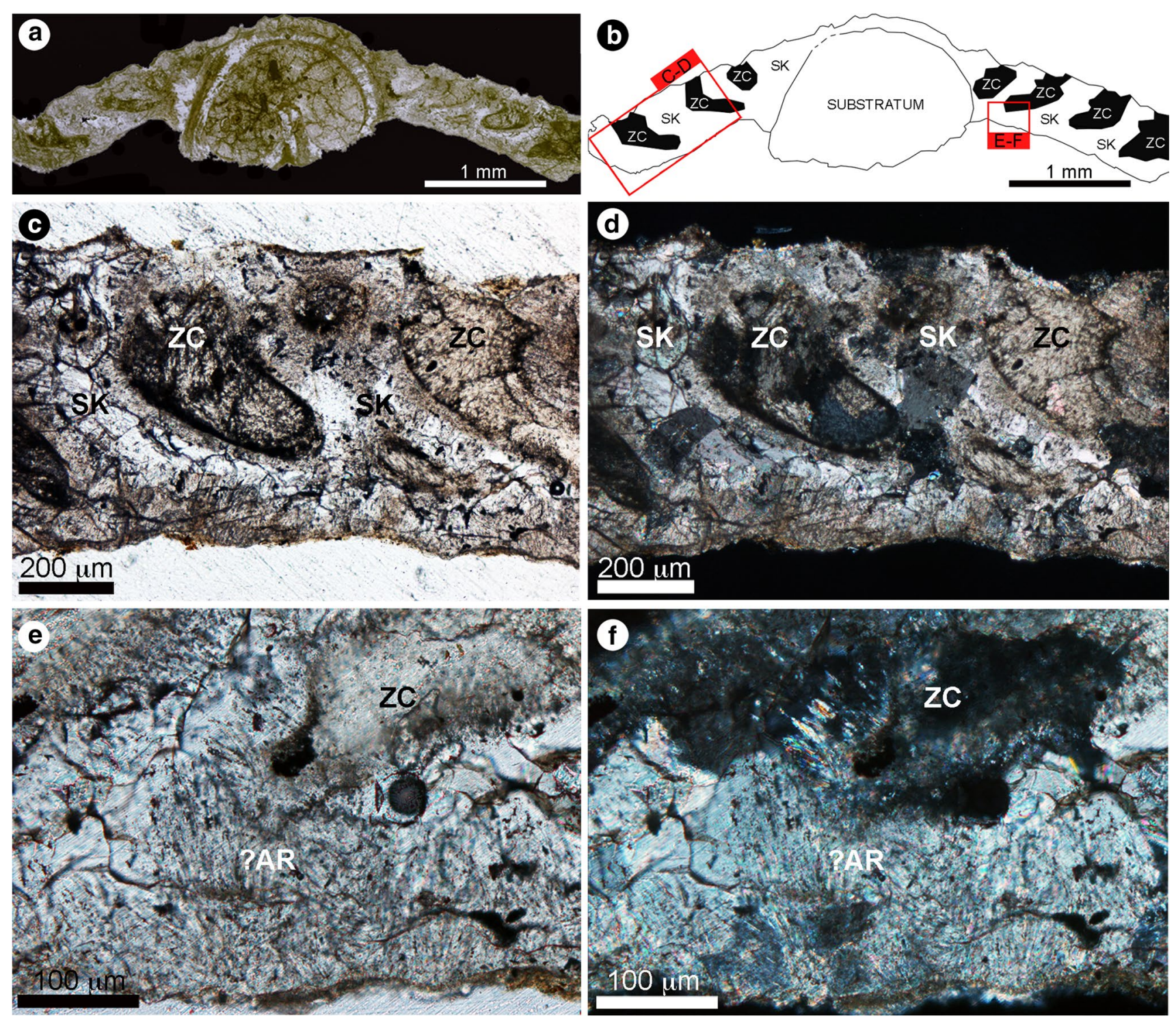

Fig. 3 Petrographic microscope images of a thin-section of Reussirella sp., Miocene, East Kalimantan, NHMUK PI BZ 7746. a General view of the vertically sectioned colony. b Interpretive diagram; ZC zooidal chamber, SK skeleton; red squares indicate parts of the colony shown in the close-up views. c, d Close-up of zooidal cham-

Miocene of East Kalimantan. All spectra indicate that the skeletons of these bryozoans are now composed of calcite.

\section{Microstructures observed in thin-sections}

\section{East Kalimantan samples}

In thin-section, the skeleton of Reussirella sp. consists of blocky, anhedral crystals of colorless to pale-brown calcite (Fig. 3). Intercrystalline boundaries are wavy or gently curved and there is no trace of growth banding. The calcite crystals show undulose extinction under crossed nicols and

bers and skeleton in plane polarized light and under crossed nicols, respectively; blocky calcite crystals are evident and show undulose extinction patterns. e, f Close-up of acicular crystals interpreted as aragonite relics (?AR) in plane polarized light and under crossed nicols, respectively

a brown pseudo-pleochroism in plane polarized light. Scattered patches within the blocky calcite of acicular crystals with high birefringence colors are interpreted as probable aragonite relics (Fig. 3e).

In the second species from the Miocene of East Kalimantan, Reptadeonella toddi, the skeletal walls comprise small, pale-brown, calcite crystals with a granular appearance (Fig. 4). Calcite crystals of the void-filling cement occupying zooidal chambers are much larger in size than those of the neomorphosed skeletal walls (Fig. 4e) and show undulose extinction under crossed nicols. 

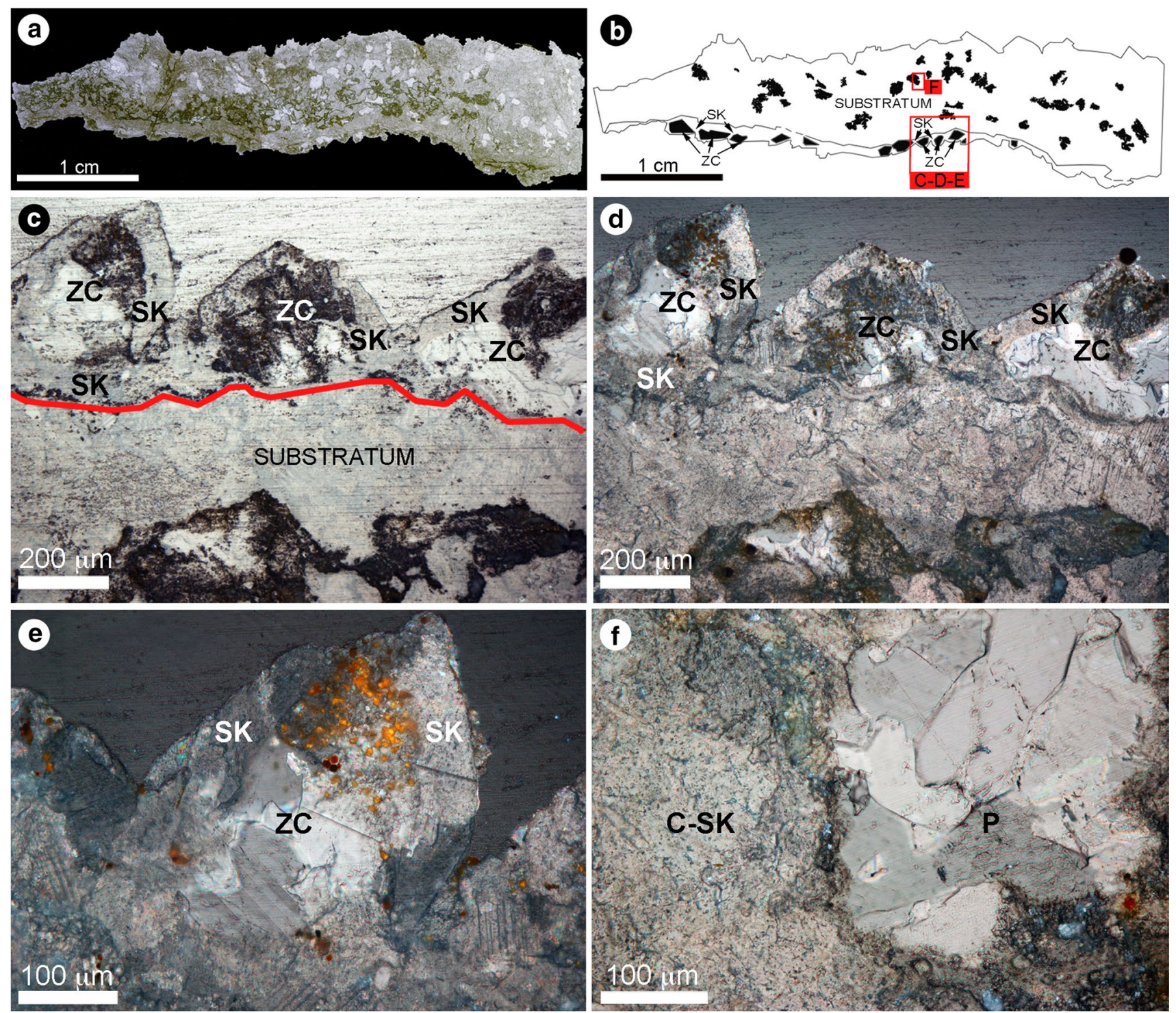

Fig. 4 Petrographic microscope images of a thin-section of Reptadeonella toddi, Miocene, East Kalimantan, NHMUK PI BZ 7747. a General view of the colony. b Interpretive diagram; ZC zooidal chamber, SK skeleton; red squares indicate parts of the colony shown in the close-up views; the substratum is the underside of a platy coral. c, d Close-up of zooidal chambers and skeleton in plane polarized light

\section{Modern and Pliocene samples}

Both the Recent and Pliocene cupuladriid samples show high birefringence colors under crossed nicols, with bundles of elongate aragonite needles that have a feather-like appearance most evident in the middle part of the lateral and on the basal walls (Fig. 5). Near the frontal surface, the acicular shape of the aragonite crystals is not clearly delineated, and the texture is granular (Fig. 5i). Distinct lateral boundaries between zooids mark the position of the intercalary cuticle (Fig. 5c, d, g). Being colorless, individual

and under crossed nicols, respectively. e Close-up of a zooid under crossed nicols; the zooidal chamber is filled with blocky crystals of calcite, while the skeleton has a granular appearance. f Close-up of the boundary between the coral skeleton (C-SK) and the calcite cement infilling a void; the neomorphosed coral and bryozoan skeletons have a similar appearance

aragonite crystals become distinct only at high magnifications in plane polarized light. However, narrow growth bands are evident at lower magnifications because they are darker in color. Distinct, much thicker, brown layers probably coincide with high contents of organic material (Fig. 5g).

In Recent Reptadeonella violacea, pale-pink needles of aragonite are organized into fan-shaped clusters (Fig. 6e-i). Darker lines, indicating growth bands and cuticular material, traverse the crystal bundles (Fig. 6g, h). Under crossed nicols the acicular aragonite is even more evident owing to 

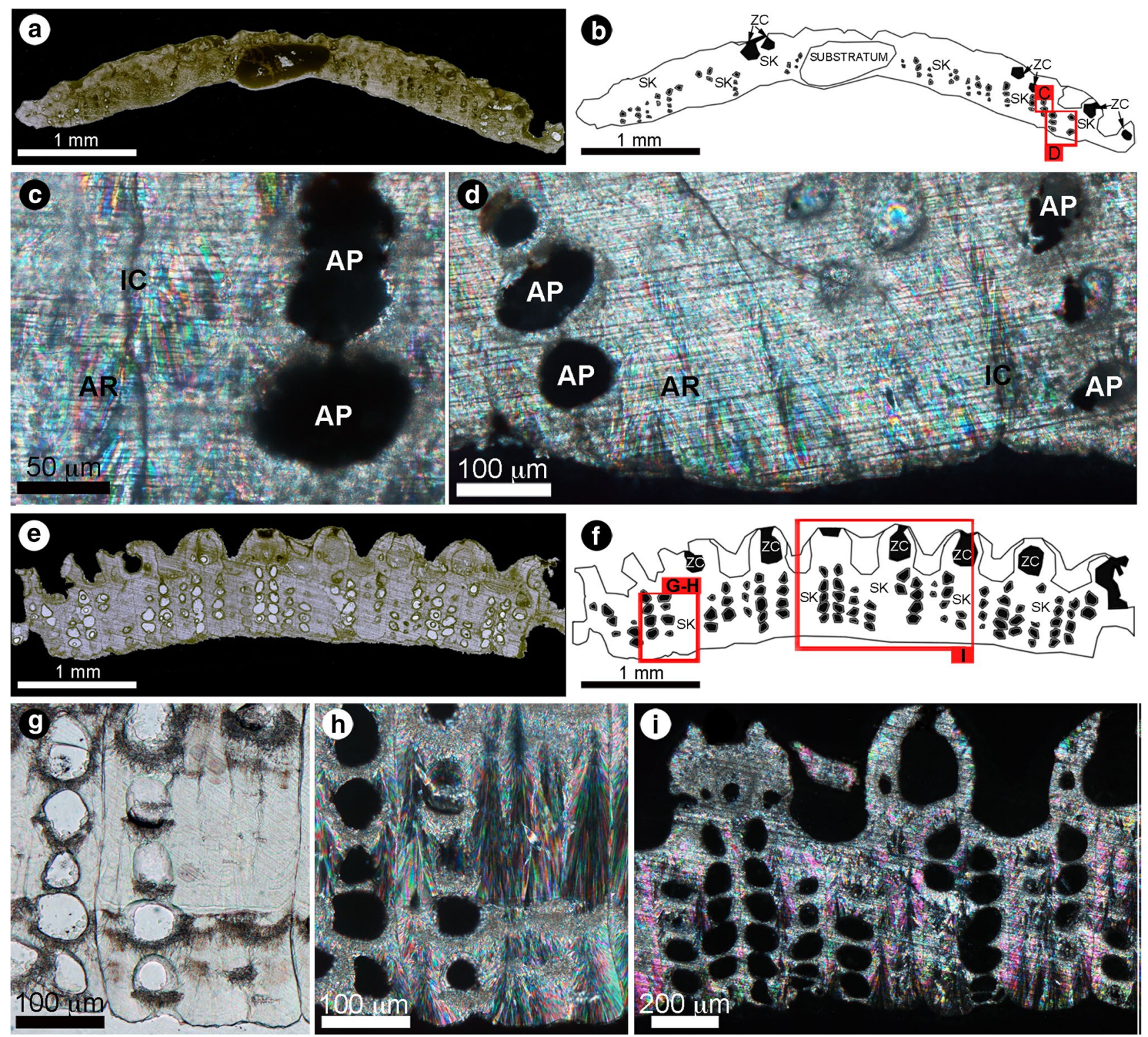

Fig. 5 Petrographic microscope images of a thin-section of Cupuladria sp.; a-d Pliocene, Moin Formation, Lomas del Mar west, Costa Rica, NHMUK PI BZ 7749; e-i Recent, 24-26 m, Islas Perlas, Panama. a, e General view of the vertically sectioned colony. b, f Interpretive diagram; ZC zooidal chamber, SK skeleton; red squares indicate parts of the colony shown in the close-up views. $\mathbf{c}$ Close-up, under crossed nicols, of the lateral wall with the intercalary cuticle (IC) marking the boundary between zooids; AP areolar

the high birefringence colors (Fig. 6i). Zooidal boundaries are marked by black contours. The very thin frontal surface of the Pliocene specimen of Reptadeonella heckeli viewed under plane polarized light consists of colorless, indistinct, evidently acicular crystals of aragonite oriented perpendicular to the wall surface (Fig. 6a-d). These crystals are more conspicuous because of their high birefringence colors under crossed nicols. pores. d Close-up of the lateral wall showing aragonite needles with high birefringence. $\mathbf{g}, \mathbf{h}$ Close-ups of the lateral wall with marked boundaries between zooids in plane polarized light and under crossed nicols, respectively; darker layers visible in $\mathbf{g}$ may coincide with high organic content; the aragonite needles have a feather-like appearance in $\mathbf{h}$. i Close-up of three zooids under crossed nicols; aragonite needles are most evident on the lateral and basal walls

\section{Ultrastructures observed under SEM}

\section{East Kalimantan samples}

The vertical section of the discoidal colony of Reussirella sp. shows clearly defined boundaries between the skeleton and the sediment filling the zooidal chambers (Fig. 7). The frontal walls consist of somewhat elongate, granular calcite crystals, 

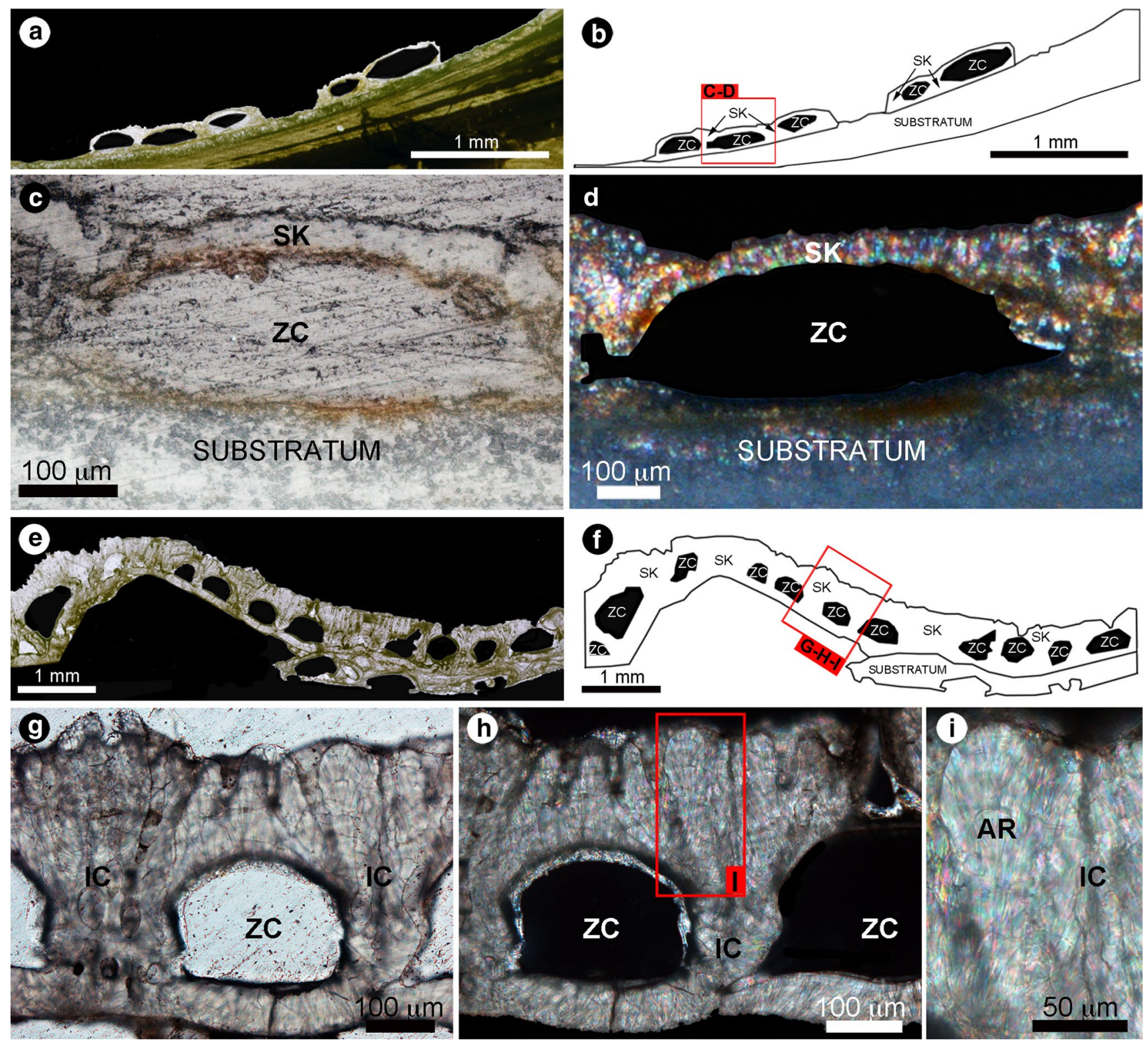

Fig. 6 Petrographic microscope images of the thin-sections of Reptadeonella spp.; a-d Reptadeonella heckeli, Pliocene, Coralline Crag Formation, Ramsholt Member, Gedgrave Cliff, Suffolk, NHMUK PI BZ 7748; e-i Reptadeonella violacea, Recent, Malta, a, e General views of the colonies encrusting bivalve shells. b, f Interpretive diagram; ZC zooidal chamber and SK skeleton. c, d Close-up of a zooid in plane polarized light and under crossed nicols, respec-

estimated to be only slightly larger size than the original skeletal crystals. In contrast, the lateral walls have much coarser calcite in the form of blocky and smooth crystals (Fig. 7b). Elements morphologically similar to those described in Pleistocene Schizoporella floridana by Sandberg (1975, p. 592; Fig. 2) and interpreted as aragonite crystal relics retaining their original orientation, are visible within the calcite crystals in both the frontal walls and lateral walls of Reussirella sp. (Fig. 7c). However, their mineralogy has not been verified. tively; aragonite crystals, colorless in plane polarized light, are elongate shape perpendicular to the skeletal wall surfaces and have high birefringence colors under crossed nicols. $\mathbf{g}$, h Close-ups of the lateral wall with boundaries between zooids well marked in plane polarized light and under crossed nicols, respectively. i Close-up of the acicular aragonite crystals of the frontal surface under crossed nicols

Zooidal chambers are filled mainly by fine-grained sediment with some cement (Fig. 7b). Traces of the former location of the cuticular layers are not clearly discernible.

The vertical section of the colony of Reptadeonella toddi, encrusting the base of a scleractinian coral, shows traces of the boundaries between the skeleton and zooidal chambers (Fig. 8). The locations of the organic cuticular layers are not clearly discernible. Elongate granular calcite crystals replace the original aragonite (Fig. 8b, c). 

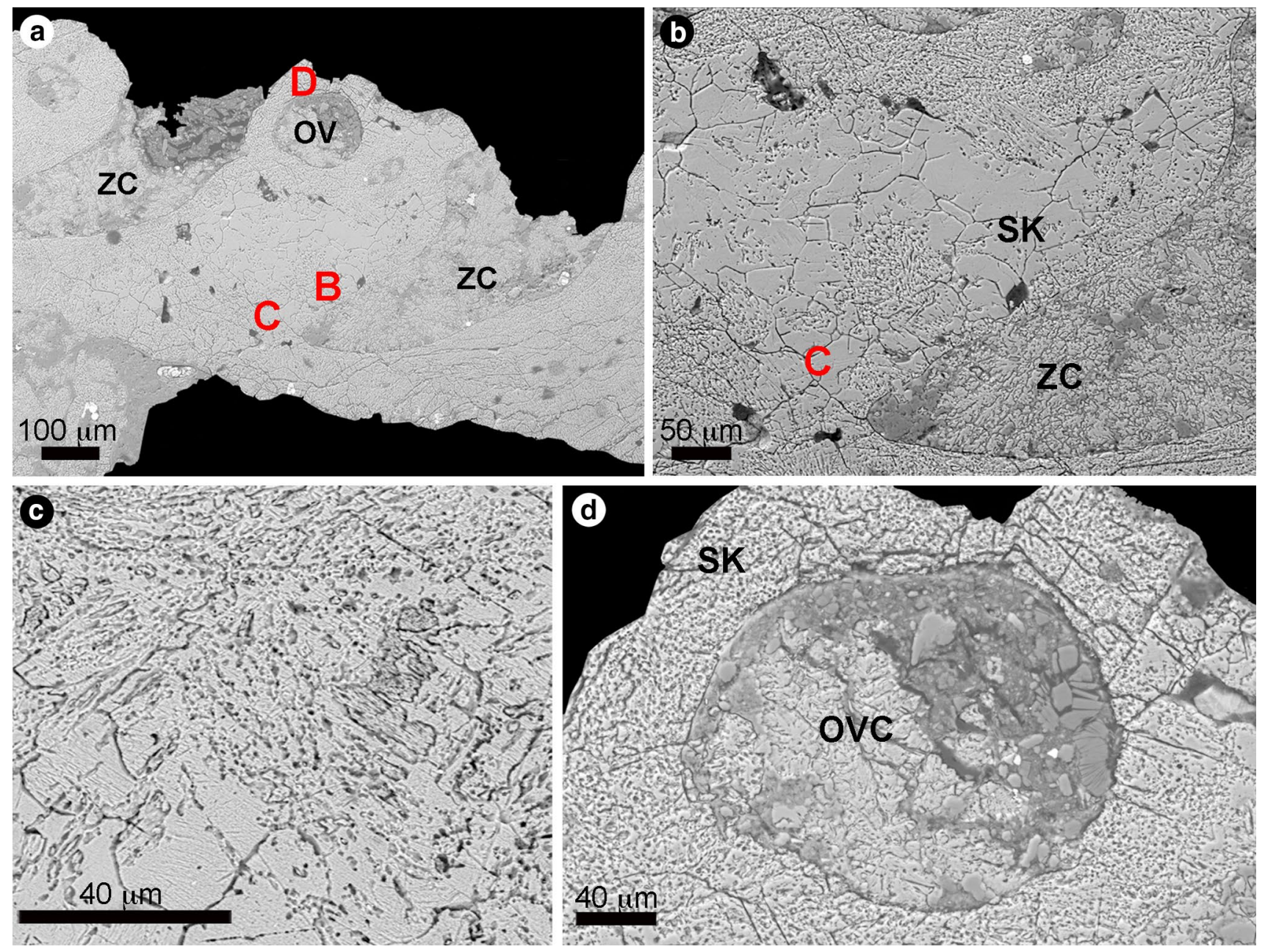

Fig. 7 Skeletal ultrastructure of Reussirella sp., Miocene, East Kalimantan, observed under SEM, NHMUK PI BZ 7746. a General view of part of the colony in vertical section; $\mathrm{ZC}$ zooidal chamber, OV ooecium, SK skeleton; red letters indicate parts of the colony shown in the close-up views. b Close-up of the boundary between the skeleton made of granular calcite crystals and the zooidal cham-

Drusy calcite cement fills the zooidal cavities, while finegrained sediment fills the areolar pores (Fig. 8b, c). A sharp, irregular contact marks the boundaries between the replaced, granular calcite skeleton and the smooth, blocky cement. As in Reussirella sp., elements morphologically similar to the solid aragonite inclusions observed in Pleistocene Schizoporella floridana by Sandberg (1975) are evident within the frontal walls of $R$. toddi. Granular calcite crystals similar to those observed in Reptadeonella toddi replace the skeleton of the encrusted coral, with voids filled by distinct blocks of clear drusy calcite cement (Fig. 8d).

\section{Modern and Pliocene samples}

A vertical section of the modern discoidal colony of Cириladria sp. shows that the pristine skeleton is composed of ber filled mainly by sediment. c Close-up of elongate acicular crystals interpreted as aragonite relics. d Close-up of an ooecium (structure for the brooding of embryos) with a marked boundary between the granular skeleton and the chamber filled mainly by sediment with some cement

numerous spherulitic fans of acicular aragonite crystals arranged perpendicular to the wall surface (Fig. 9). Parallel, undulose growth bands traverse the crystallite fans. Distinct sheets of organic matrix are clearly evident as cuticles at the basal and lateral junctions. Cuticle boundaries appear highly irregular (crenulated), sometimes undulose and with sharp peaks (Fig. 9d). No appreciable morphological differences are evident in the aragonite skeleton of the Pliocene Cupuladria compared to the modern sample (Fig. 10). Again, acicular aragonite crystals are organized into bundles, elongated perpendicular to the wall surface, with traces of growth bands and the location of the former lateral and basal cuticles still evident. The most manifest difference between the modern specimen and the fossil is in the presence of numerous microfractures in the fossil skeleton. 

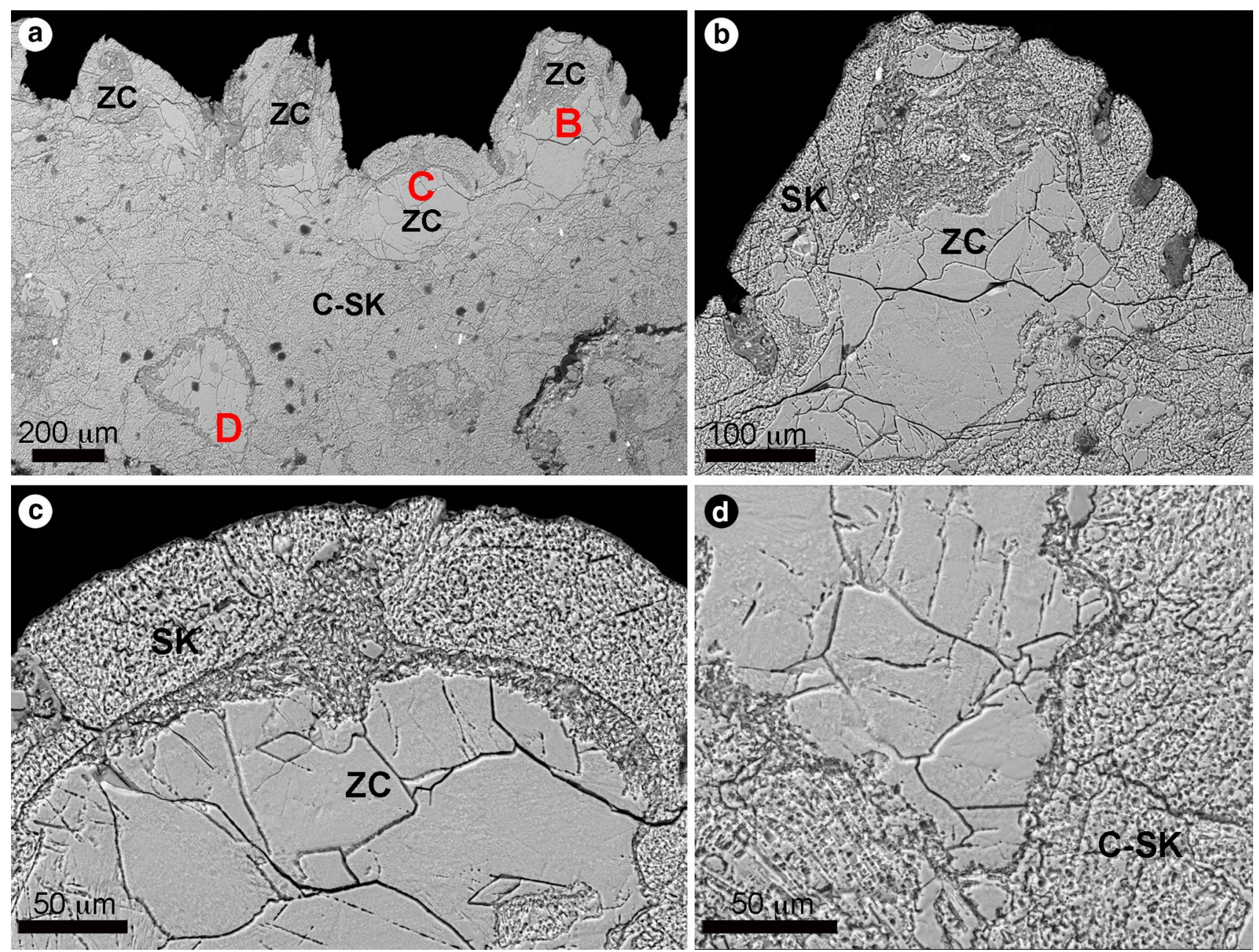

Fig. 8 Skeletal ultrastructure of Reptadeonella toddi, Miocene, East Kalimantan, observed under SEM, NHMUK PI BZ 7747. a General view of part of the colony in vertical section; ZC zooidal chamber, C-SK coral skeleton; red letters indicate parts of the colony shown in the close-up views. b, c Close-up views of two zooids; the boundary

The Recent Reptadeonella violacea skeleton is composed of numerous parallel layers of acicular aragonite crystals oriented perpendicular to the frontal surface and traversed by irregularly undulose growth bands (Fig. 11). Organic cuticular layers are evident on the frontal, lateral and basal surfaces (Fig. 11c, d).

\section{Discussion}

Evidence for neomorphism of skeletal aragonite has been documented in detail for several groups of marine invertebrates of various ages and from different localities. Notable examples are:

1. Scleractinian corals, e.g., Late Pleistocene Acropora palmata, A. cervicornis and Montastrea annularis from between the skeleton, made of granular calcite crystals, and the zooidal chambers, filled by sediment and blocky calcite cement, is evident. d Close-up of the boundary between the granular skeleton of the coral and the calcite cement filling a void

Barbados (Pingitore 1970, 1976; James 1974); M. аnnularis from the Pleistocene Key Largo Limestone in Miami, Florida (Martin et al. 1985); and Porites sp. from emergent Pleistocene to Holocene Pacific reefs (Rabier et al. 2008).

2. Molluscs, e.g., shells of the bivalve Neomiodon from the Jurassic of Scotland (Sandberg and Hudson 1983); the bivalves Neomiodon and Unio and the gastropod Viviparus from the Late Jurassic-Early Cretaceous of southern England (Maliva and Dickson 1992); the Pleistocene gastropod Strombus gigas from Grand Cayman (Rehman et al. 1994) and the Key Largo Limestone in Miami (Martin et al. 1985); Middle Jurassic bivalves from Lincolnshire (England) tentatively assigned to Modiolus, Pholadomya and Isognomon (Hendry et al. 1995); rudist bivalves from Cretaceous carbonate facies of southeastern France, the Gulf 

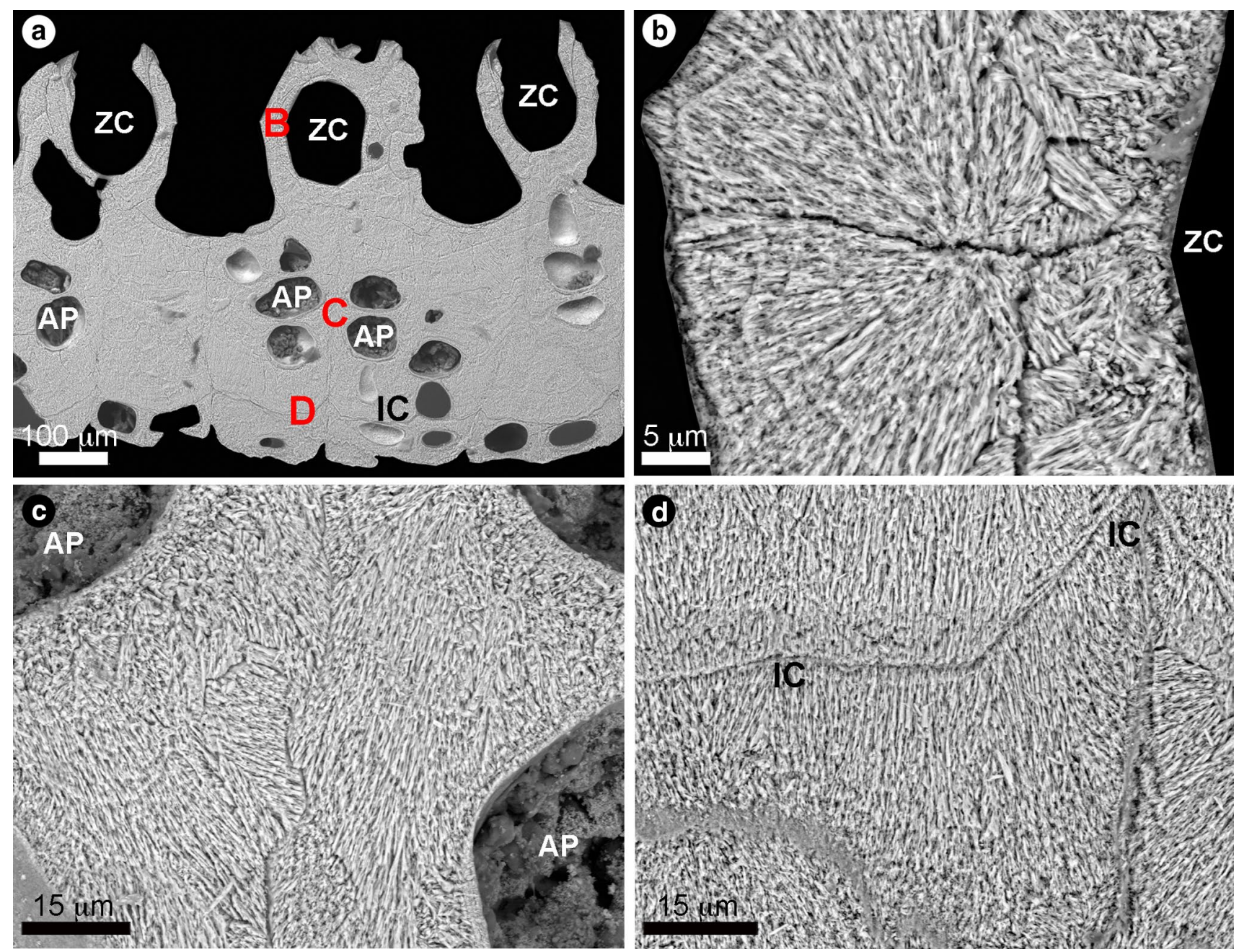

Fig. 9 Skeletal ultrastructure of Cupuladria sp., Recent, 24-26 m, Islas Perlas, Panama, observed under SEM. a General view of part of the colony in vertical section; ZC zooidal chamber, AP areolar pores, IC intercalary cuticle; red letters indicate parts of the colony shown

Coast and central Texas, Cuba, Puerto Rico and Jamaica (Al-Aasn and Veizer 1986); and ammonite shells from the Early Jurassic Blue Lias Formation of Dorset, England (Jordan et al. 2015).

However, the only detailed study of skeletal aragonite neomorphism in a bryozoan is Sandberg (1975) description of calcitization of the originally aragonitic parts of the skeleton of the bimineralic cheilostome Schizoporella floridana from the Pleistocene Miami Limestone of southern Florida.

Two cheilostome bryozoan genera-Reussirella and Reptadeonella-which today biomineralize skeletons entirely of aragonite are unexpectedly present in Miocene muddy reefs deposits from East Kalimantan lacking aragonitic molluscs presumably as a result of diagenetic dissolution. Laser Raman spectroscopy showed the in the close-up views. b Close-ups of a vertical wall made of acicular aragonite crystals. c Close-up of a lateral wall with numerous spherulitic fans of acicular aragonite. d Boundary between the lateral and basal wall showing the position of the crenulated intercalary cuticle

mineralogy of these bryozoans to be calcite. The micromorphology of their skeletal walls in thin-section and under the SEM is consistent with calcitization, comprising equant, anhedral crystals having undulose extinction patterns and containing small fibrous patches interpreted as likely aragonite relics. These characters contrast with the acicular microstructures seen in examples of closely related recent species, as well as in some Pliocene fossils that have retained their aragonitic compositions. Influx of fine-grained siliciclastic sediment into the Miocene reefs of East Kalimantan from which the calcitized bryozoans were collected probably retarded dissolution of the bryozoan aragonite (cf. Brachert and Dullo 2000) and allowed calcitization to occur.

Considerable interest has focused on the mechanisms controlling the calcitization of aragonite skeletons during 

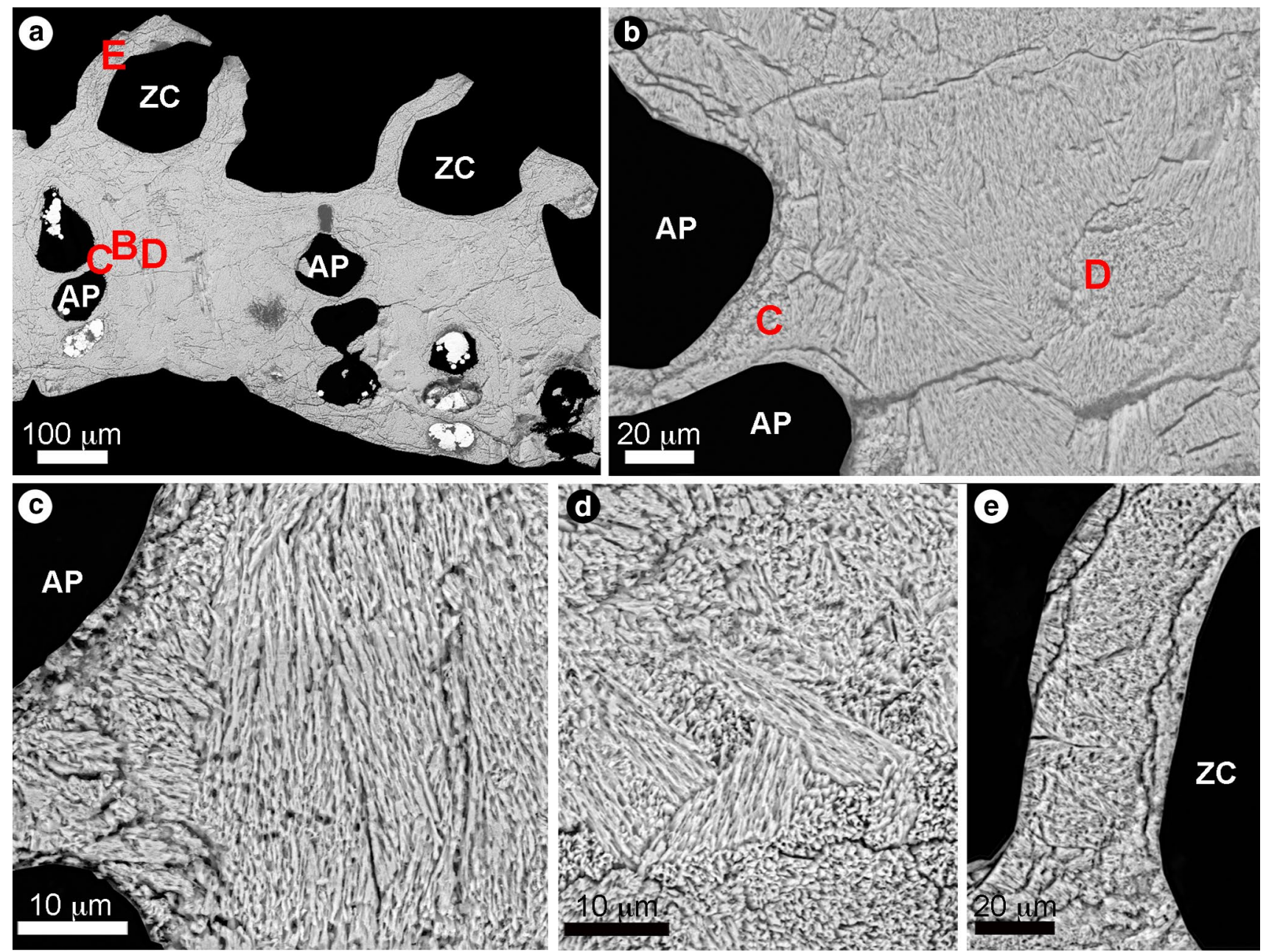

Fig. 10 Skeletal ultrastructure of Cupuladria sp., Pliocene, Moin Formation, Lomas del Mar west, Costa Rica, observed under SEM, NHMUK PI BZ 7749. a General view of part of the colony in vertical section; ZC zooidal chamber, AP areolar pores; red letters indicate parts of the colony shown in the close-up views. b Close-up views

subaerial diagenesis. Two main modes for aragonite to calcite transformation have been proposed based on observations of microtexture and trace element concentrations: (1) a broad advancing zone of calcification, with partial or complete shell dissolution and subsequent calcite spar precipitation; and (2) fine-scale, volume by volume replacement of aragonite by calcite along a thin solution film without substantial void formation, and with relict aragonite crystals, organic matter, and original skeletal microstructure preserved as ghosts in the calcite spar (e.g., Maliva et al. 2000). These two modes have been observed both separately and in the same samples, and have been related respectively to phreatic and vadose diagenetic environments (Pingitore 1976). The presence of patches of acicular crystallites interpreted as relict aragonite suggests that the process responsible for calcitization of the bryozoans from of lateral walls with numerous microfractures and acicular aragonite crystals. c, $\mathbf{d}$ Close-up of the spherulitic fans of acicular aragonite in the lateral wall. e Close-up of the frontal wall in which aragonite needles are less evident and fractures are present

East Kalimantan was at least in part by volume-by-volume replacement along a solution film.

The primitive biomineral in cheilostome bryozoans is calcite but multiple clades have independently evolved the capability of biomineralizing aragonite through geological time (Taylor et al. 2009; Benedix et al. 2014). Among cheilostomes that utilize aragonite are two families of freeliving cheilostomes, Lunulitidae and Cupuladriidae. Lunulitids first appeared in the Coniacian, were entirely calcitic throughout most of the Late Cretaceous but introduced aragonite in the form of bimineralic skeletons in the Maastrichtian, and later evolved monomineralic skeletons of aragonite (Taylor et al. 2009). Cupuladriids appeared after lunulitids in the fossil record, possibly in the Paleocene (Gorodiski and Balavoine 1962), and when well preserved are found always to have skeletons composed of aragonite 

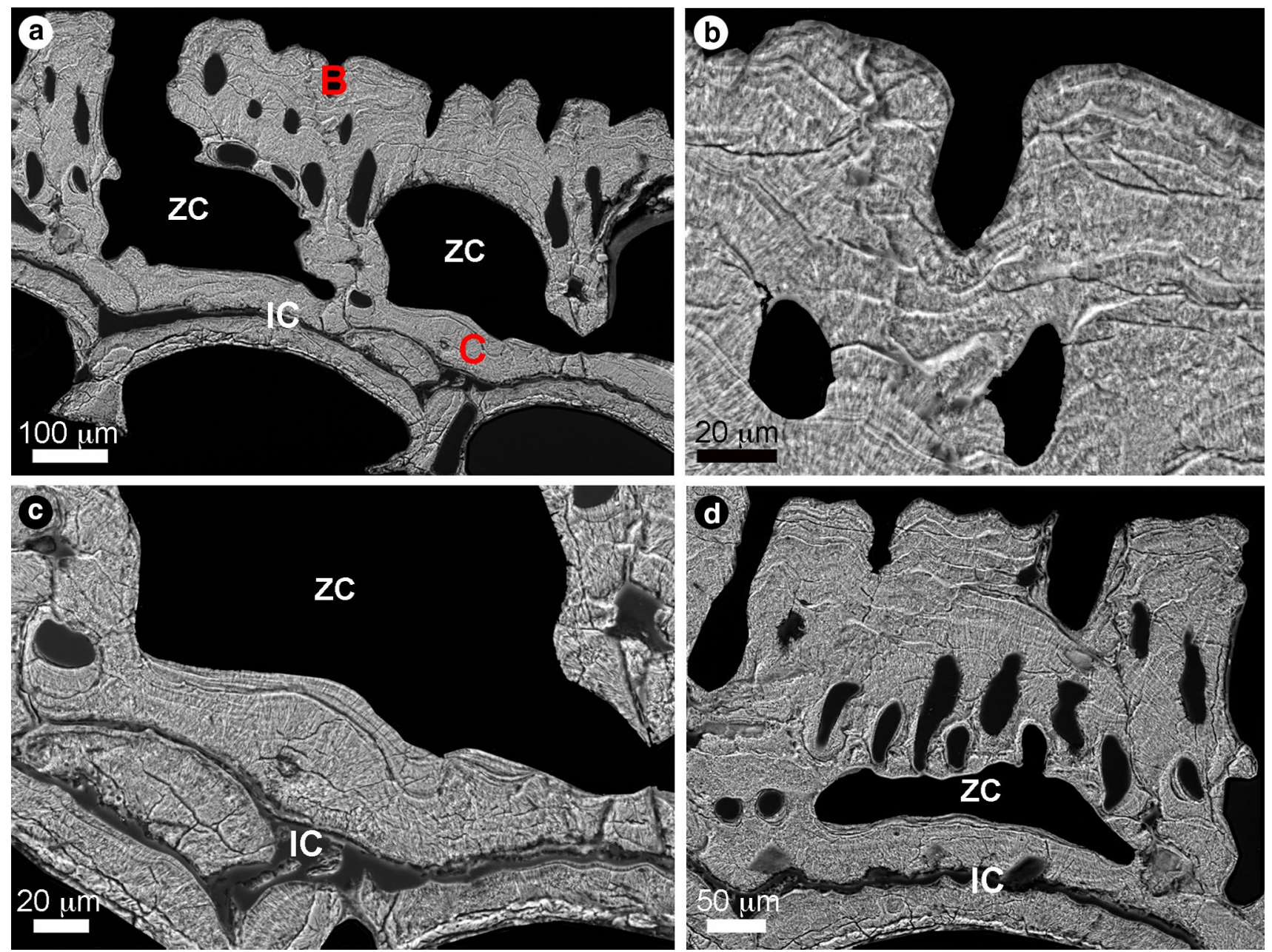

Fig. 11 Skeletal ultrastructure of Reptadeonella violacea, recent, Malta, observed under SEM. a General view of part of the colony in vertical section; ZC zooidal chamber, IC intercalary cuticle; red letters indicate parts of the colony shown in the close-up views.

(e.g., Taylor et al. 2014). For example, Raman spectroscopy of the pristine skeleton of an un-named species of Cириladria from the Bartonian of Bende Ameki, Nigeria figured by Taylor (2012; fig. 3) showed the skeleton to have an aragonitic composition (new data). The description here of a calcitized example of the cupuladriid Reussirella sp. from the Miocene of East Kalimantan demonstrates the potential for aragonitic cupuladriids to be preserved by calcitization. This supports the interpretation of coarsely preserved early cupuladriids as originally aragonitic, e.g., the Spanish Eocene species Mesosecos simplex Faura and Canu (Taylor 2012). The probability of a primitively aragonitic skeleton in cupuladriids provides a contrast with the primitively calcitic skeleton of lunulitids, the other major group of freeliving cheilostomes that evolved earlier than cupuladriids.

The broader significance of the current study is twofold. Firstly, it raises the question of why the aragonitic b Close-ups of a frontal wall with growth bands and acicular aragonite crystals. c Close-up of a basal wall with the position of the intercalary cuticle evident. d Close-up of a zooid showing growth bands, acicular aragonite crystals and intercalary cuticle bryozoans and scleractinian corals in the muddy reefs were calcitized but the molluscs were not. One possibility is that calcitization may be related to the contrasting skeletal microstructures between the finely acicular bryozoans and corals on the one hand and the larger crystallites of the mollusc shells on the other. Martin et al. (1985) suggested that differences in skeletal porosity between the coral Montastrea and the gastropod Strombus in the Pleistocene of Florida strongly influenced neomorphism, which occurred six times faster in the more porous coral. Whatever the exact processes concerned, taxonomic bias in calcitization may be a more general phenomenon in the fossil record that needs to be considered in paleoecological and evolutionary studies.

Secondly, it has been assumed in the past that any bryozoans present in deposits lacking aragonitic molluscs must have had calcitic skeletons, as those with aragonite 
skeletons would have suffered the same fate as the aragonitic molluscs. However, the current study shows that calcitization of originally aragonitic bryozoans can occur even if all of the aragonitic molluscs have been dissolved during diagenesis. Moreover, the surface preservation of the calcitized bryozoans can be very good (Fig. 2), providing no hints that the skeleton has been neomorphosed. Biofacies analysis should take into account selective preservation of some of the originally aragonitic components of the original biota through calcitization while other parts are lost.

Acknowledgments EDM research received support from the SYNTHESYS Project http://www.synthesys.info/ which is financed by European Community Research Infrastructure Action under the FP7 Integrating Activities Programme. Tony Wighton prepared the thinsections and Tomasz Goral assisted with SEM.

Open Access This article is distributed under the terms of the Creative Commons Attribution 4.0 International License (http://creativecommons.org/licenses/by/4.0/), which permits unrestricted use, distribution, and reproduction in any medium, provided you give appropriate credit to the original author(s) and the source, provide a link to the Creative Commons license, and indicate if changes were made.

\section{References}

Al-Aasn IS, Veizer J (1986) Diagenetic stabilization of aragonite and low-magnesium calcite, I. Trace elements in rudists. J Sediment Petrol 56:138-152

Allen GP, Chambers JLC (1998) Sedimentation in the Modern and Miocene Mahakam Delta. Jakarta, Indonesia, Indonesian Petroleum Association

Benedix G, Jacob DE, Taylor PD (2014) Bimineralic bryozoan skeletons: a comparison of three modern genera. Facies 60:389-403

Brachert TC, Dullo WC (2000) Shallow burial diagenesis of skeletal carbonates: selective loss of aragonite shell material (Miocene to Recent, Queensland Plateau and Queensland Trough, NE Australia) -implications for shallow cool-water carbonates. Sediment Geol 136:169-187

Bush AM, Bambach RK (2004) Did alpha diversity increase during the Phanerozoic? Lifting the veils of taphonomic, latitudinal, and environmental biases. J Geol 112:625-642

Caron V, Nelson CS (2009) Diversity of neomorphic fabrics in New Zealand Plio-Pleistocene cool-water limestones: insights into aragonite alteration pathways and controls. J Sediment Res 79:226-246

Cherns L, Wright P (2000) Missing molluscs as evidence of largescale, early skeletal aragonite dissolution in a Silurian sea. Geology 28:791-794

Cherns LJ, Wheeley R, Wright VP (2008) Taphonomic windows and molluscan preservation. Palaeogeog Palaeoclimatol Palaeoecol 270:220-229

Folk RL (1965) Some aspects of recrystallization in ancient limestones. In: Pray LC, Murray RC (eds) Dolomitization and limestone diagenesis: a symposium, vol. 13. Soc Econ Paleontol Mineral Spec Publ, pp 14-48

Foote M, Crampton JS, Beu AG, Nelson CS (2015) Aragonite bias, and lack of bias, in the fossil record: lithological, environmental, and ecological controls. Paleobiology 41:245-265

Gorodiski A, Balavoine P (1962) Bryozoaires Crétacés et Eocènes du Senegal. Bull Bur Rech Géol Min 4:1-16
Hall R, Nichols G (2002) Cenozoic sedimentation and tectonics in Borneo: climatic influences on orogenesis. In: Jones SJ, Frostick L (eds) Sediment flux to basins: causes, controls and consequences, vol. 191. Geol Soc London Spec Publ, pp 5-22

Hendry JP, Ditchfield PW, Marshall JD (1995) Two-stage neomorphism of Jurassic aragonitic bivalves: implications for early diagenesis. J Sed Res 65:214-224

James NP (1974) Diagenesis of scleractinian corals in the subaerial vadose environment. J Paleontol 48:785-799

Jordan N, Allison PA, Hill J, Sutton MD (2015) Not all aragonitic molluscs are missing: taphonomy and significance of a unique shelly lagerstätte from the Jurassic of SW Britain. Lethaia. doi:10.1111/let.12126

Kidwell SM (2005) Shell composition has no net impact on large scale evolutionary patterns in mollusks. Science 307:914-917

Kidwell SM, Best MMR, Kaufmann RS (2005) Taphonomic tradeoffs in tropical marine death assemblages: differential time averaging, shell loss, and probable bias in siliciclastic vs. carbonate facies. Geology 33:729-732

Kowalewski M, Gürs K, Nebelsick JH, Oschmann W, Piller WE, Hoffmeister AP (2002) Multivariate hierarchical analyses of Miocene mollusk assemblages of Europe: paleogeographic, paleoecological, and biostratigraphic implications. Geol Soc Am Bull 114:239-256

Lokier SW, Wilson MEJ, Burton LM (2009) Marine biota response to clastic sediment influx: a quantitative approach. Palaeogeogr Palaeoclimatol Palaeoecol 281:25-42

Maliva RG (1995) Recurrent neomorphic and cement microtextures from different diagenetic environments, Quaternary to Late Neogene carbonates, Great Bahama Bank. Sediment Geol 97:1-7

Maliva RG (1998) Skeletal aragonite neomorphism-quantitative modelling of a two-water diagenetic system. Sediment Geol 121:179-190

Maliva RG, Dickson JAD (1992) The mechanism of skeletal aragonite neomorphism: evidence from neomorphosed mollusks from the upper Purbeck Formation (Late Jurassic-Early Cretaceous), southern England. Sediment Geol 76:221-232

Maliva RG, Missimer TM, Dickson JAD (2000) Skeletal aragonite neomorphism in Plio-Pleistocene sandy limestones and sandstones, Hollywood, Florida, USA. Sediment Geol 136:147-154

Marshall N, Novak V, Cibaj I, Krijgsman W, Renema W, Young J, Fraser N, Limbong A, Morley R (2015) Dating Borneo deltaic deluge: middle Miocene progradation of the Mahakam Delta. Palaios 30:7-25

Martin GD, Wilkinson BH, Lohmann KC (1985) The role of skeletal porosity in aragonite neomorphism-Strombus and Montastrea from the Pleistocene Key Largo Limestone, Florida. J Sediment Petrol 56:194-203

McAlester AL (1962) Mode of preservation in early Paleozoic pelecypods and its morphologic and ecologic significance. J Paleontol 36:69-73

Moss SJ, Chambers JLC (1999) Tertiary facies architecture in the Kutai Basin, Kalimantan, Indonesia. J Asian Earth Sci 17:157-181

Moss SJ, Wilson MEJ (1998) Biogeographic implications of the Tertiary paleogeographic evolution of Sulawesi and Borneo. In: Hall R, Holloway JD (eds) Biogeography and geological evolution of Southeast Asia. Backhuys Publishers, Leiden, pp 133-163

Novak V, Renema W (2015) Larger foraminifera as environmental discriminators in Miocene mixed carbonate-siliciclastic systems. Palaios 30:40-52

Novak V, Santodomingo N, Rösler A, Di Martino E, Braga JC, Taylor PD, Johnson KG, Renema W (2013) Environmental reconstruction of a late Burdigalian (Miocene) patch reef in deltaic deposits (East Kalimantan, Indonesia). Palaeogeogr Palaeoclimatol Palaeoecol 374:110-122 
Pingitore NE Jr (1970) Diagenesis and porosity modification in Acropora palmata, Pleistocene of Barbados, West Indies. J Sediment Res 40:712-721

Pingitore NE Jr (1976) Vadose and phreatic diagenesis: processes, products and their recognition in corals. J Sediment Res 46:985-1006

Rabier C, Anguy Y, Cabioch G, Genthon P (2008) Characterization of various stages of calcitization in Porites sp. corals from uplifted reefs-case studies from New Caledonia, Vanuatu, and Futuna (South-West Pacific). Sediment Geol 211:73-86

Rehman J, Jones B, Hagan TH, Coniglio M (1994) The influence of sponge borings on aragonite-to-calcite inversion in Late Pleistocene Strombus gigas from Grand Cayman, British west Indies. J Sediment Res 64:174-179

Sandberg PA (1975) Bryozoan diagenesis: bearing on the nature of the original skeleton of rugose corals. J Paleontol 49:587-606

Sandberg PA, Hudson JD (1983) Aragonite relic preservation in Jurassic calcite-replaced bivalves. Sedimentology 30:879-892

Santodomingo N, Novak V, Pretković V, Marshall N, Di Martino E, Lo Giudice Capelli E, Rösler A, Reich S, Braga JC, Renema W, Johnson KG (2015) A diverse patch reef from turbid habitats in the middle Miocene (East Kalimantan, Indonesia). Palaios 30:128-149

Smith AM, Key MM Jr, Gordon DP (2006) Skeletal mineralogy of bryozoans: taxonomic and temporal patterns. Earth-Sci Rev 78:287-306

Sorby HC (1879) The structure and origin of limestones. Proc Geol Soc London 35:56-95

Taylor PD (2012) Identity of Mesosecos Faura \& Canu, 1917, a neglected early genus of free-living Cupuladriidae (Bryozoa, Cheilostomata) from the Spanish Eocene. Batalleria 17:32-38
Taylor PD, Di Martino E (2014) Why is the tropical Cenozoic fossil record so poor for bryozoans. In: Rosso A, Wyse Jackson PN, Porter J (eds) Bryozoan Studies 2013, Studi Trent Sci Nat, pp 249-257

Taylor PD, Kudryavtsev AB, Schopf JW (2008) Calcite and aragonite distributions in the skeletons of bimineralic bryozoans as revealed by Raman spectroscopy. Invertebr Biol 127:87-97

Taylor PD, James NP, Bone Y, Kuklinski P, Kyser TK (2009) Evolving mineralogy of cheilostome bryozoans. Palaios 24:440-452

Taylor PD, James NP, Phillips G (2014) Mineralogy of cheilostome bryozoans across the Eocene-Oligocene boundary in Mississippi, USA. Palaeobiodiversity Palaeoenvironments 94:425-438

Tomašových A, Schlögl J (2008) Analyzing variations in cephalopod abundances in shell concentrations: the combined effects of production and density-dependent cementation rates. Palaios 23:648-666

Wilson MEJ (2005) Development of equatorial delta-front patch reef during the Neogene, Borneo. J Sediment Res 75:116-134

Wilson MEJ, Moss SJ (1999) Cenozoic paleogeographic evolution of Sulawesi and Borneo. Palaeogeogr Palaeoclimatol Palaeoecol 145:303-307

Wilson MEJ, Chambers JLC, Manning C, Nas DS (2012) Spatio-temporal evolution of a temporary carbonate platform margin and adjacent basinal deposits. Sediment Geol 271:1-27

Wright P, Cherns L, Hodges P (2003) Missing molluscs: field testing taphonomic loss in the Mesozoic through early large-scale aragonite dissolution. Geology 31:211-214 